\title{
Inlet Port Valve Device
}

National Cancer Institute

\section{Source}

National Cancer Institute. Inlet Port Valve Device. NCI Thesaurus. Code C50251.

A valve that controls the flow of fluids in through the wall of a chamber. 